\title{
Protocol to the African Charter on Human and Peoples' Rights on the Establishment of an African Court on Human and Peoples' Rights
}

The Member States of the Organization of African Unity hereinafter referred to as the OAU, States Parties to the African Charter on Human and Peoples' Rights:

Considering that the Charter of the Organization of African Unity recognizes that freedom, equality, justice, peace and dignity are essential objectives for the achievement of the legitimate aspirations of the African peoples;

Noting that the African Charter on Human and Peoples' Rights reaffirms adherence to the principles of human and peoples' rights, freedoms and duties contained in the declarations, conventions and other instruments adopted by the Organization of African Unity, and other international organizations;

Recognizing that the twofold objective of the African Charter on Human and Peoples' Rights is to ensure on the one hand promotion and on the other protection of human and peoples' rights, freedoms and duties;

Recognizing further, the efforts of the African Commission on Human and Peoples' Rights in the promotion and protection of human and peoples' rights since its inception in 1987;

Recalling resolution AHG/Res. 230 (XXX) adopted by the Assembly of Heads of State and Government in June 1994 in Tunis, Tunisia, requesting the SecretaryGeneral to convene a Government experts' meeting to ponder, in conjunction with the African Commission, over the means to enhance the efficiency of the African Commission and to consider in particular the establishment of an African Court on Human and Peoples' Rights;

Noting the first and second Government legal experts' meetings held respectively in Cape Town, South Africa (September, 1995) and Nouakchott, Mauritania (April, 1997), and the third Government Legal Experts meeting held in Addis Ababa, Ethiopia (December, 1997), which was enlarged to include Diplomats;

Firmly convinced that the attainment of the objectives of the African Charter on Human and Peoples' Rights requires the establishment of an African Court on Human and Peoples' Rights to complement and reinforce the functions of the African Commission on Human and Peoples' Rights. 


\section{HAVE AGREED AS FOLLOWS:}

\section{Article 1 ESTABLISHMENT OF THE COURT}

There shall be established within the Organization of African Unity an African Court on Human and Peoples' Rights (hereinafter referred to as <the Court>), the organization, jurisdiction and functioning of which shall be governed by the present Protocol.

\section{Article 2 RELATIONSHIP BETWEEN THE COURT AND THE COMMISSION}

The Court shall, bearing in mind the provisions of this Protocol, complement the protective mandate of the African Commission on Human and Peoples' Rights (hereinafter referred to as "the Commission") conferred upon it by the African Charter on Human and Peoples' Rights (hereinafter referred to as "the Charter").

\section{Article 3 JURISDICTION}

1. The jurisdiction of the Court shall extend to all cases and disputes submitted to it concerning the interpretation and application of the Charter, this Protocol and any other relevant Human Rights instrument ratified by the States concerned.

2. In the event of a dispute as to whether the Court has jurisdiction, the Court shall decide.

\section{Article 4 ADVISORY OPINIONS}

1. At the request of a Member State of the OAU, the OAU, any of its organs, or any African organization recognized by the OAU, the Court may provide an opinion on any legal matter relating to the Charter or any other relevant human rights instruments, provided that the subject matter of the opinion is not related to a matter being examined by the Commission.

2. The Court shall give reasons for its advisory opinions provided that every judge shall be entitled to deliver a separate or dissenting decision.

\section{Article 5 ACCESS TO THE COURT}

1. The following are entitled to submit cases to the Court

a The Commission;

b The State Party which has lodged a complaint to the Commission;

c The State Party against which the complaint has been lodged at the Commission;

d The State Party whose citizen is a victim of human rights violation;

e African Intergovernmental Organizations.

2. When a State Party has an interest in a case, it may submit a request to the Court to be permitted to join. 
3. The Court may entitle relevant Non Governmental Organizations (NGOs) with observer status before the Commission, and individuals to institute cases directly before it, in accordance with article 34 (6) of this Protocol.

\section{Article 6 ADMISSIBILITY OF CASES}

1. The Court, when deciding on the admissibility of a case instituted under article 5 (3) of this Protocol, may request the opinion of the Commission which shall give it as soon as possible.

2. The Court shall rule on the admissibility of cases taking into account the provisions of article 56 of the Charter.

3. The Court may consider cases or transfer them to the Commission.

\section{Article 7 SOURCES OF LAW}

The Court shall apply the provisions of the Charter and any other relevant human rights instruments ratified by the States concerned.

\section{Article 8 CONSIDERATION OF CASES}

The Rules of Procedure of the Court shall lay down the detailed conditions under which the Court shall consider cases brought before it, bearing in mind the complementarity between the Commission and the Court.

\section{Article 9 AMICABLE SETTLEMENT}

The Court may try to reach an amicable settlement in a case pending before it in accordance with the provisions of the Charter.

\section{Article 10 HEARINGS AND REPRESENTATION}

1. The Court shall conduct its proceedings in public. The Court may, however, conduct proceedings in camera as may be provided for in the Rules of Procedure.

2. Any party to a case shall be entitled to be represented by a legal representative of the party's choice. Free legal representation may be provided where the interests of justice so require.

3. Any person, witness or representative of the parties, who appears before the Court, shall enjoy protection and all facilities, in accordance with international law, necessary for the discharging of their functions, tasks and duties in relation to the Court.

\section{Article 11 COMPOSITION}

1. The Court shall consist of eleven judges, nationals of Member States of the OAU, elected in an individual capacity from among jurists of high moral character and of recognized practical, judicial or academic competence and experience in the field of human and peoples' rights. 
2. No two judges shall be nationals of the same State.

Article 12 NOMINATIONS

1. States Parties to the Protocol may each propose up to three candidates, at least two of whom shall be nationals of that State.

2. Due consideration shall be given to adequate gender representation in the nomination process.

\section{Article 13 LIST OF CANDIDATES}

1. Upon entry into force of this Protocol, the Secretary-General of the OAU shall request each State Party to the Protocol to present, within ninety (90) days of such a request, its nominees for the office of judge of the Court.

2. The Secretary-General of the OAU shall prepare a list in alphabetical order of the candidates nominated and transmit it to the Member States of the OAU at least thirty days prior to the next session of the Assembly of Heads of State and Government of the OAU hereinafter referred to as "the Assembly".

\section{Article 14 ELECTIONS}

1. The judges of the Court shall be elected by secret ballot by the Assembly from the list referred to in Article 13 (2) of the present Protocol.

2. The Assembly shall ensure that in the Court as a whole there is representation of the main regions of Africa and of their principal legal traditions.

3. In the election of the judges, the Assembly shall ensure that there is adequate gender representation.

\section{Article 15 TERM OF OFFICE}

1. The judges of the Court shall be elected for a period of six years and may be reelected only once. The terms of four judges elected at the first election shall expire at the end of two years, and the terms of four more judges shall expire at the end of four years.

2. The judges whose terms are to expire at the end of the initial periods of two and four years shall be chosen by lot to be drawn by the Secretary-General of the OAU immediately after the first election has been completed.

3. A judge elected to replace a judge whose term of office has not expired shall hold office for the remainder of the predecessor's term.

4. All judges except the President shall perform their functions on a part-time basis. However, the Assembly may change this arrangement as it deems appropriate. 


\section{Article 16 OATH OF OFFICE}

After their election, the judges of the Court shall make a solemn declaration to discharge their duties impartially and faithfully.

\section{Article 17 INDEPENDENCE}

1. The independence of the judges shall be fully ensured in accordance with international law.

2. No judge may hear any case in which the same judge has previously taken part as agent, counsel or advocate for one of the parties or as a member of a national or international court or a commission of enquiry or in any other capacity. Any doubt on this point shall be settled by decision of the Court.

3. The judges of the Court shall enjoy, from the moment of their election and throughout their term of office, the immunities extended to diplomatic agents in accordance with international law.

4. At no time shall the judges of the Court be held liable for any decision or opinion issued in the exercise of their functions.

\section{Article 18 INCOMPATIBILITY}

The position of judge of the Court is incompatible with any activity that might interfere with the independence or impartiality of such a judge or the demands of the office, as determined in the Rules of Procedure of the Court.

\section{Article 19 CESSATION OF OFFICE}

1. A judge shall not be suspended or removed from office unless, by the unanimous decision of the other judges of the Court, the judge concerned has been found to be no longer fulfilling the required conditions to be a judge of the Court.

2. Such a decision of the Court shall become final unless it is set aside by the Assembly at its next session.

\section{Article 20 VACANCIES}

1. In case of death or resignation of a judge of the Court, the President of the Court shall immediately inform the Secretary General of the Organization of African Unity, who shall declare the seat vacant from the date of death or from the date on which the resignation takes effect.

2. The Assembly shall replace the judge whose office became vacant unless the remaining period of the term is less than one hundred and eighty (180) days.

3. The same procedure and considerations as set out in Articles 12, 13 and 14 shall be followed for the filling of vacancies. 


\section{Article 21 PRESIDENCY OF THE COURT}

1. The Court shall elect its President and one Vice-President for a period of two years. They may be re-elected only once.

2. The President shall perform judicial functions on a full-time basis and shall reside at the seat of the Court.

3. The functions of the President and the Vice-President shall be set out in the Rules of Procedure of the Court.

\section{Article 22 EXCLUSION}

If a judge is a national of any State which is a party to a case submitted to the Court, that judge shall not hear the case.

Article 23 QUORUM

The Court shall examine cases brought before it, if it has a quorum of at least seven judges.

\section{Article 24 REGISTRY OF THE COURT}

1. The Court shall appoint its own Registrar and other staff of the registry from among nationals of Member States of the OAU according to the Rules of Procedure.

2. The office and residence of the Registrar shall be at the place where the Court has its seat.

\section{Article 25 SEAT OF THE COURT}

1. The Court shall have its seat at the place determined by the Assembly from among States parties to this Protocol. However, it may convene in the territory of any Member State of the OAU when the majority of the Court considers it desirable, and with the prior consent of the State concerned.

2. The seat of the Court may be changed by the Assembly after due consultation with the Court.

\section{Article 26 EVIDENCE}

1. The Court shall hear submissions by all parties and if deemed necessary, hold an enquiry. The States concerned shall assist by providing relevant facilities for the efficient handling of the case.

2. The Court may receive written and oral evidence including expert testimony and shall make its decision on the basis of such evidence. 


\section{Article 27 FINDINGS}

1. If the Court finds that there has been violation of a human or peoples' right, it shall make appropriate orders to remedy the violation, including the payment of fair compensation or reparation.

2. In cases of extreme gravity and urgency, and when necessary to avoid irreparable harm to persons, the Court shall adopt such provisional measures as it deems necessary.

\section{Article 28 JUDGMENT}

1. The Court shall render its judgment within ninety (90) days of having completed its deliberations.

2. The judgment of the Court decided by majority shall be final and not subject to appeal.

3. Without prejudice to sub-article 2 above, the Court may review its decision in the light of new evidence under conditions to be set out in the Rules of Procedure.

4. The Court may interpret its own decision.

5. The judgment of the Court shall be read in open court, due notice having been given to the parties.

6. Reasons shall be given for the judgment of the Court.

7. If the judgment of the Court does not represent, in whole or in part, the unanimous decision of the judges, any judge shall be entitled to deliver a separate or dissenting opinion.

\section{Article 29 NOTIFICATION OF JUDGMENT}

1. The parties to the case shall be notified of the judgment of the Court and it shall be transmitted to the Member States of the OAU and the Commission.

2. The Council of Ministers shall also be notified of the judgment and shall monitor its execution on behalf of the Assembly.

\section{Article 30 EXECUTION OF JUDGMENT}

The States parties to the present Protocol undertake to comply with the judgment in any case to which they are parties within the time stipulated by the Court and to guarantee its execution.

\section{Article 31 REPORT}

The Court shall submit to each regular session of the Assembly, a report on its work during the previous year. The report shall specify, in particular, the cases in which a State has not complied with the Court's judgment. 


\section{Article 32 BUDGET}

Expenses of the Court, emoluments and allowances for judges and the budget of its registry, shall be determined and borne by the OAU, in accordance with criteria laid down by the $\mathrm{OAU}$ in consultation with the Court.

\section{Article 33 RULES OF PROCEDURE}

The Court shall draw up its Rules and determine its own procedures. The Court shall consult the Commission as appropriate.

\section{Article 34 RATIFICATION}

1. This Protocol shall be open for signature and ratification or accession by any State Party to the Charter.

2. The instrument of ratification or accession to the present Protocol shall be deposited with the Secretary-General of the OAU.

3. The Protocol shall come into force thirty days after fifteen instruments of ratification or accession have been deposited.

4. For any State Party ratifying or acceding subsequently, the present Protocol shall come into force in respect of that State on the date of the deposit of its instrument of ratification or accession.

5. The Secretary-General of the OAU shall inform all Member States of the entry into force of the present Protocol.

6. At the time of the ratification of this Protocol or any time thereafter, the State shall make a declaration accepting the competence of the Court to receive cases under article 5 (3) of this Protocol. The Court shall not receive any petition under article 5 (3) involving a State Party which has not made such a declaration.

7. Declarations made under sub-article (6) above shall be deposited with the Secretary General, who shall transmit copies thereof to the State parties.

\section{Article 35 AMENDMENTS}

1. The present Protocol may be amended if a State Party to the Protocol makes a written request to that effect to the Secretary-General of the OAU. The Assembly may adopt, by simple majority, the draft amendment after all the States Parties to the present Protocol have been duly informed of it and the Court has given its opinion on the amendment.

2. The Court shall also be entitled to propose such amendments to the present Protocol as it may deem necessary, through the Secretary-General of the OAU.

3. The amendment shall come into force for each State Party which has accepted it thirty days after the Secretary-General of the OAU has received notice of the acceptance. 